\title{
Proceeding
}

9th INSHS International Christmas Sport Scientific Conference, 4-6 December 2014. International Network of Sport and Health

Science. Szombathely, Hungary

\section{The effectiveness of weight-reduction stays at the children's treatment centre of Křetín}

\author{
JANA JUŘÍKOVÁ $1 \square$, JARMILA PRUDILOVÁ 2 \\ ${ }^{1}$ Faculty of Sports Studies, Department of Kinesiology, Masaryk University, Brno, Czech Republic \\ 2 The Children's Treatment Centre Kretín, Czech Republic
}

\begin{abstract}
Juríková, J., \& Prudilová, J. (2015). The effectiveness of weight-reduction stays at the children's treatment centre of kretín. J. Hum. Sport Exerc., 9(Proc1), pp.S471-S481. The Children's Treatment Centre of Křetín not only treats obesity, but also respiratory diseases and locomotors system impairments. This study focuses on 25 children who were sent to the Centre by a paediatrician in order to reduce their body weight. These children were prescribed a slimming program which included physical activity and an appropriate diet. The curative stay lasted 4 weeks. After the treatment was over, it may be concluded that all children had reduced their weight. The weight reduction in boys was $4.91 \mathrm{~kg}$ and in girls $3.56 \mathrm{~kg}$ on average. Key words: CHILDREN, BODY WEIGHT, BODY HEIGHT, OVERWEIGHT, BMI, OBESITY, EATING HABITS, PHYSICAL ACTIVITY.
\end{abstract}

Corresponding author. Masaryk University, Department of Sports Studies, Kamenice 5, 62500 Brno-Bohunice, Czech Republic

E-mail: jurikova@fsps.muni.cz

9th INSHS International Christmas Sport Scientific Conference, 4-6 December 2014. International Network of Sport and

Health Science. Szombathely, Hungary.

JOURNAL OF HUMAN SPORT \& EXERCISE ISSN 1988-5202

(c) Faculty of Education. University of Alicante

doi:10.14198/jhse.2015.10.Proc1.41 


\section{INTRODUCTION}

Obesity

Obesity has existed throughout mankind's existence. It was even prevalent in prehistoric human society. Since the turn of the millennium, obesity has become the most common metabolic disease, having resulted from living conditions and lifestyle. Thus there is a positive energy balance. Lately this positive energy balance, especially in developed countries, has been boosted by a significant decrease in energy expenditure due to sedentary lifestyle (Hainer et al., 2004). Obesity occurs as a result of a positive energy balance, when the equilibrium is disrupted as the energy intake exceeds its expenditure.

Although obesity is predominantly a problem of developed countries, its prevalence in developing countries is growing rapidly. The prevalence of obesity in the adult population is $10-20 \%$ in most western European countries and $20-25 \%$ in North America. The situation is a great deal worse in Eastern Europe where 40 $\%$ of women suffer from obesity. Nowadays, obesity exists in countries where it hardly ever existed in the past (e.g. China, Thailand, and Indonesia).

Obesity is defined by the presence of excessive body fat. The highest number of obese people occurred in the age range 50 - 60. In all populations obesity is higher in women than men. In terms of ethnic origin, the highest prevalence of obesity was found among the black population, then followed by the Mexican population. The lowest incidence of obesity is found in the Caucasian population. People with higher education and higher economic status show a lower prevalence of obesity and vice versa. Getting married also leads to an increase in obesity. While it is supposed that weight increases with the number of pregnancies, this effect is not of high significance. From the viewpoint of genetic dispositions, the prevalence of obesity in the family is typically affected by family traditions. Increased risk for obesity is particularly connected with fat consumption. Smoking increases energy expenditure and thus influences the prevalence of obesity. Low consumption of alcohol leads to weight gain, however heavy alcoholics might be of lower weight. Physical activity plays a crucial role - the rise in obesity is directly linked with the prevalence of hypokinesis.

The obesity rate in the Czech Republic is one of the highest in Europe. According to data from the International Obesity Task Force (IOTF), Czech women place $4^{\text {th }}$ and men even place $3^{\text {rd }}$ in obesity prevalence in Europe. The obesity percentage for the Czech population has reached $16 \%$ for men and 20 $\%$ for women $(\mathrm{BMI}>30)$, and up to $66 \%$ of men and $54 \%$ of women are overweight $(\mathrm{BMI}>25)$ (Svačina, 2000).

Since the second half of the last century, the number of obese people has been growing rapidly. This upward trend can be observed worldwide and not only in adult populations, the rise in the number of obese children is particularly alarming. Since 2002 , the problem of overweight and obesity has been claimed by the World Health Organization (WHO) as the sixth most significant health risk to human health, and thus it represents a higher risk than smoking (Hlúbik, 2005).

Obesity is a disease which originates from multiple causes. It can be characterized by the increase of body fat as the result of both genetic predisposition and environmental factors. Obesity itself increases morbidity and mortality, and significantly reduces the quality of life (Aldhoon Hainerová, 2009). 


\section{Childhood obesity}

The issue of obesity does not merely concern adults, but children as well. The incidence of obesity in youth leads to a high probability of adult obesity (Rikanová, 2012). Prevalence of childhood obesity worldwide is growing steadily and it affects younger and younger age categories. Obesity in children and adolescents has the same causes as in adults, which means high energy intake and low energy expenditure. Genetic factors also play a role in the prevalence of obesity. Poor and irregular dietary habits also play their role.

Defining childhood obesity is a much more complex process than defining obesity in general. During their growth and development, children's bodies change their BMI curve, and therefore existing definitions of childhood obesity might vary somewhat. Overweight is often defined within the interval of the 85th and 95th BMI percentiles and obesity is defined at or above the 95th percentile of BMI. In the Czech Republic the recommended definition of overweight is between $90^{\text {th }}$ - $97^{\text {th }}$ percentiles of $\mathrm{BMI}$ and obesity at or above the 97th percentile of BMI, both values related to age and sex (Aldhoon Hainerová, 2009).

Diagnostics of obesity should be based on detailed family and personal history that answer questions concerning smoking, allergies, dietary habits, alcohol consumption, physical activity and mental health. During basic physical examination it is necessary to monitor a person's weight and height, BMI, and waist and hip girth. Laboratory tests should include determination of fasting blood glucose, lipid profile and liver function tests.

Treatment of obese and overweight people is aimed at weight loss and reducing the adipose tissue. A comprehensive approach is applied for obesity treatment. The primary step is a low-calorie diet together with physical activity. Regular physical activity enhances general health and is a natural method of weight reduction. Movement helps to lower blood pressure and supports blood circulation in all parts of the body (Sigmund et Sigmundová, 2011). Additional treatment methods include pharmacotherapy, and, in the case of morbid obesity (BMI $\geq 40$ ), surgery is an option (Kunešová, 2004).

\section{Childhood obesity treatment}

Primary prevention of childhood obesity falls under the purview of preventive examinations carried out by general practitioners for children and adolescents. Cooperation with other professionals (e.g. child psychologists) is more than convenient. The crucial step, however, is the education of the entire family and the motivation of all family members to make long-term changes in their dietary habits (Pastucha et al., 2010).

Treatment of childhood obesity is determined by its degree and the child's age. The basic treatment is a change of lifestyle. Persistence is one of the key factors of successful treatment because it is always a long-term process that should be planned individually in accordance with the needs of the specific child. Prevention and treatment of childhood obesity require a comprehensive approach as well. Children follow the poor dietary and exercise habits of their parents. It is advisable to prevent these behavioural patterns because it is comparatively easier to change the bad habits of children than adults. The aim of prevention is to create appropriate dietary and eating habits of children and to maintain these habits over the long-term, as well as to establish a child's need for physical activity and to involve entire family into the process of weight loss (Aldhoon Hainerová, 2009).

When a child is already overweight or obese and treatment in the home environment is not sufficient, there are a number of obesitological institutes in the Czech Republic which provide specialists in childhood obesity and treatment. The service of the therapeutic civic association STOB (= Stop Obesity) focuses on 
parallel treatment of mother and child and is available in most regions of the country. The obesity might be complementarily treated at a spa or specialized weight-loss camp. Spa treatment has a long tradition in the Czech Republic.

This work presents the results of measurements obtained in children undergoing the treatment at The Children's Treatment Centre of Křetín.

The Children's Treatment Centre Křetín

The Treatment Centre is situated in the picturesque village of Křetín. It occupies a former château, which was built in 1861 by the Desfours Walderode family from Netherlands. The last owner of the chateau was a builder, Hubert Svoboda, from whom the mansion was confiscated in 1945. In 1948 it was rebuilt into a sanatorium for weakened children. Since 2010 it has merged with the children's speleotherapy centre in Ostrov u Macochy and the children's centre of movement disorders in Boskovice. Its status has been changed from a sanatorium to treatment centre (Prudilová, 2014).

Besides children with overweight and obesity, the Treatment Centre also treats children with nutritional intake disorders (anorexia, asthenia), repeatedly ill children, in particular those with breathing difficulties (relapsing, persistent cough, chronic rhinitis, asthma, allergic rhinitis, etc.) and children with locomotors system impairments (poor body posture, mild types of scoliosis). Even though the Centre is situated in the historic château, it is furnished in a modern style. Besides newly furnished rooms, the building offers a fitness room with a gym, hydrotherapy, including a sea bath, whirlpool, sauna and small basins for alternating foot baths. Upon recommendation of physicians, children undergo numerous treatments supervised by physiotherapists (curative physical exercising, inhalations, nasal baths, biolamp, magnetotherapy, podoscope examination, spirometry etc.). The building itself is surrounded by a splendid Château Park established in the 19th century. The park includes a nature trail around rare wooded species, a FIT-trail training route, a large and a small playground, mini-golf, Russian ninepins and trampolines. During warm weather, an outdoor heated swimming pool $(12 \mathrm{~m} \times 6 \mathrm{~m})$ is available in the garden, and children can bathe there from May to October (www.detskelecebny.cz).

After admission, children go through medical entrance examinations which determine overweight or obesity and diagnose other possible health problems. Body weight and the ratio of body fat are measured by the In-Body device. Body height, chest, waist and hip girth are also measured. Over the course of the 4-week treatment children are subjected to a reduction programme which includes 6 meals a day: breakfast, snack, lunch, snack, dinner and late dinner (the later dinner always consists of a fruit). Meals are prepared in accordance with dietary system for diet no. 8 - weight reduction diet, diet no. 13 - food for children aged 3 to 15 and diet no. 12 - toddler's diet aged 1.5 to 3 . Menus are adjusted to the nutritional needs of children and adolescents, with respect to possible allergies, food intolerance and other special diets. Menus may be easily customized to all these requirements. Since different age groups have different nutritional needs, menus are categorized according to age: younger children up to the age of 8 , and older children, over 8 . Children further undergo a treatment program that includes daily exercise in the gym, afternoon long walks, Nordic walking, passing FIT-trails in the park around the spa, swimming in the outdoor swimming pool and a large number of other rehabilitation treatment options based on doctor's decisions (magnetotherapy, sauna, whirlpool baths, inhalations, alternating foot baths, wind machines, massage, sea bath, and others). 


\section{MATERIAL AND METHODS}

Body weight measurement

The children's body weight was measured by the InBody 220 device which determines not only body weight, but also, when the body height is given, can determine on the basis of bioelectrical impedance, other characteristics such as BMI, the amount of fat tissue, proportion of water in the body and lean muscle mass. Children entered the InBody 220 device barefoot. The accuracy of body weight was measured to 0.1 $\mathrm{kg}$.

Body height measurement

Body height was measured by anthropometry $\pm 0.5 \mathrm{~cm}$. During measuring, children stood straight, heels together, tips slightly apart. The head is vertically upward, like looking into the distance (Frankfurt horizontal).

\section{Body mass index in children}

To evaluate BMI in children we use percentile graphs that compare an individual child against the population standards for children of the same age. Graphs differ for boys and girls. Percentile graphs outline the zone in which the BMI value is considered normal - this value corresponds to the age and gender of the child. The curves above and below this zone indicate the percentage of children of the same age who have the same BMI value. Zone between the $25^{\text {th }}$ and $75^{\text {th }}$ percentile, in which $50 \%$ of all values belong, is considered a zone of medium values. Values above the $85^{\text {th }}$ percentile are often defined as overweight in children, and obesity is defined above the $95^{\text {th }}$ percentile. Conversely, underweight values are found at the bottom part of the graph, below the curve indicating the 3rd percentile, and the interval of low weight occurs between the $3^{\text {rd }}$ and the $10^{\text {th }}$ percentile. Percentile graphs of the World Health Organization are shown below - graph 1 represents boys and graph 2 represents girls.

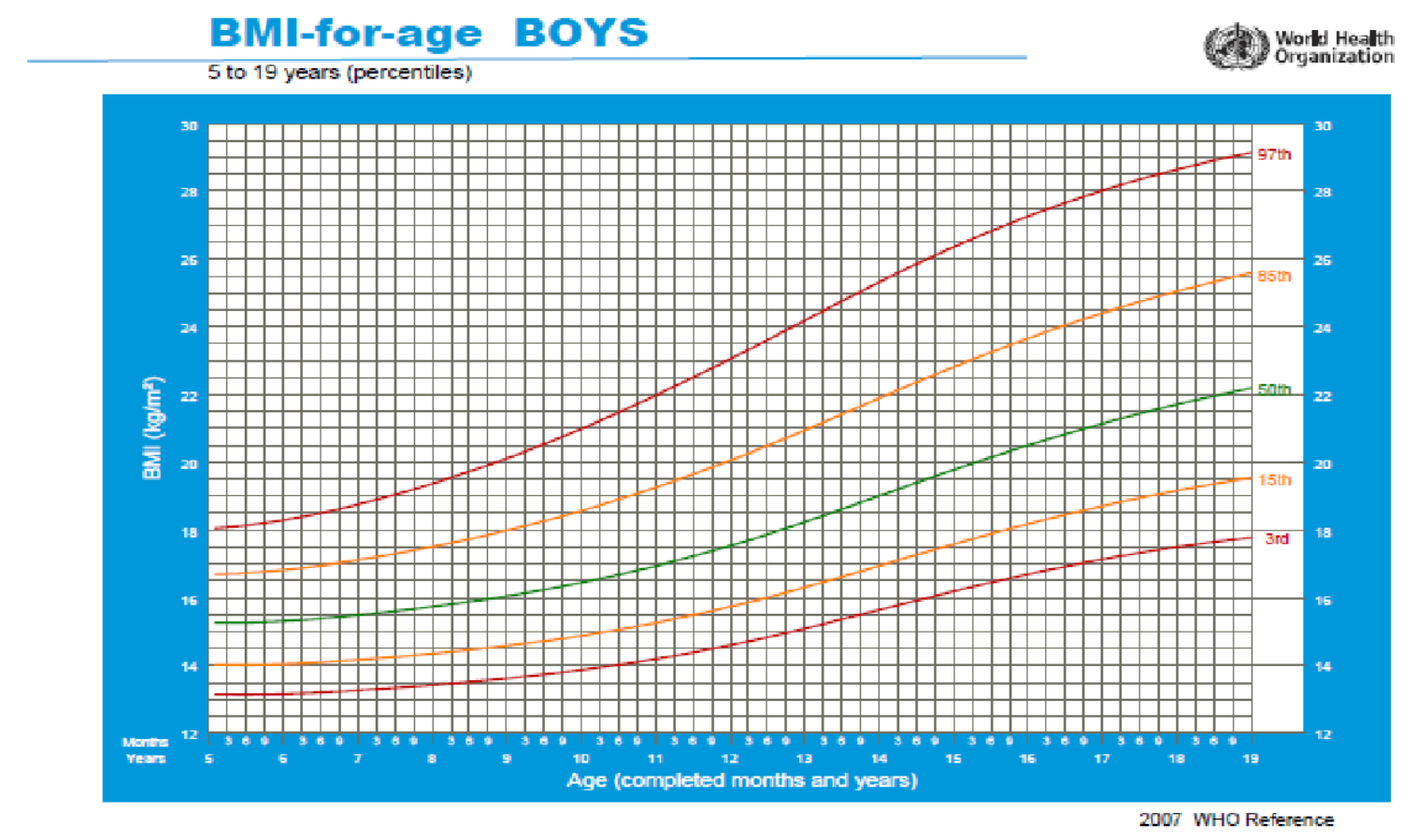

Figure 1. 1BMI percentile graph - boys 


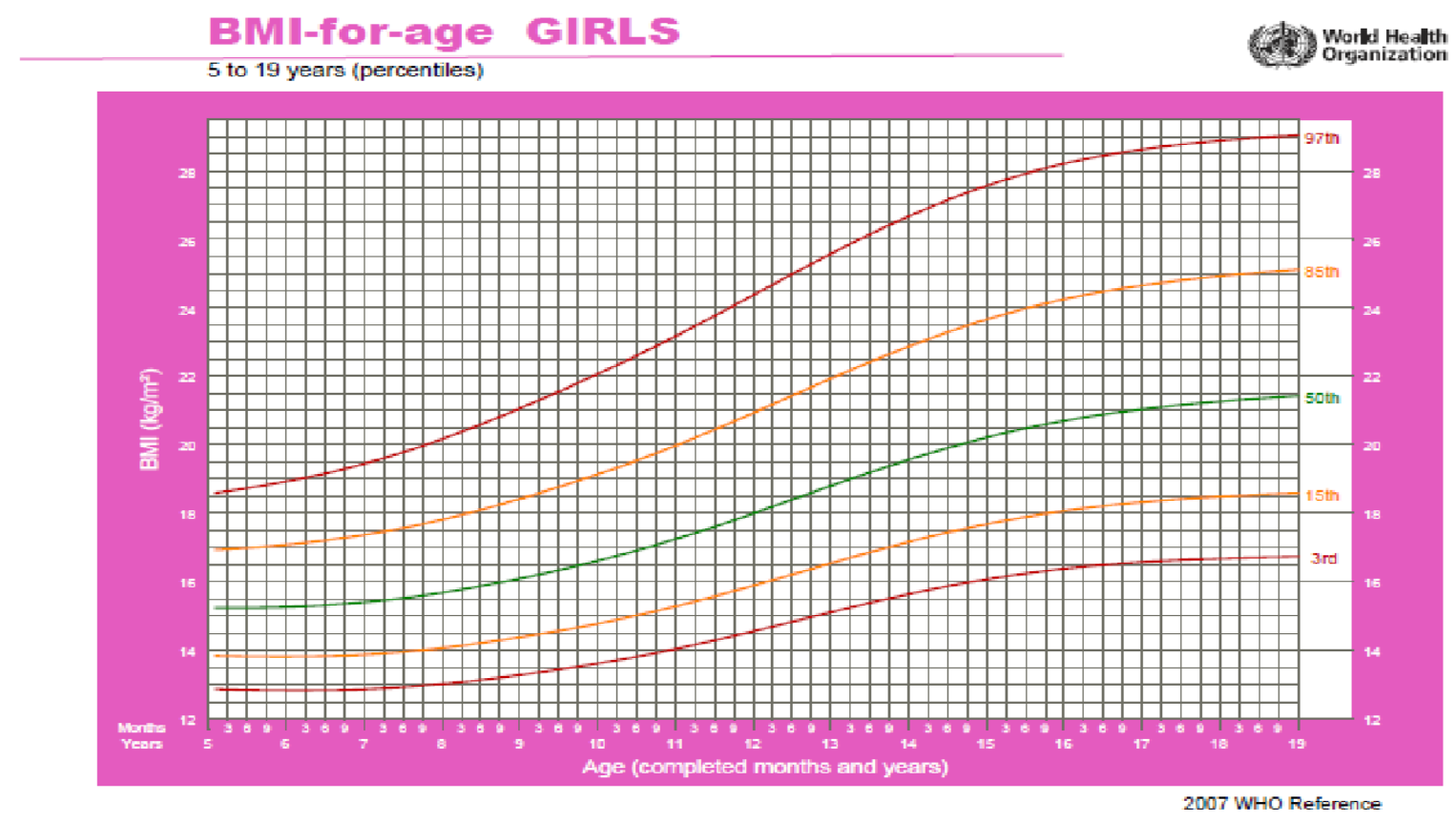

Figure 2. BMl percentile graph - girls

Table 1 shows the classification of overweight and obesity according to BMl percentile in children.

Table 1. Classification of overweight and obesity according to BMl percentile in children

\begin{tabular}{lcc}
\hline & Czech Republic & World \\
\hline Overweight & $90^{\text {th }}-97^{\text {th }}$ BMl percentile & $85^{\text {th }}-95^{\text {th }}$ BMl percentile \\
Obesity & $>97^{\text {th }}$ BMl percentile & $>95^{\text {th }}$ BMl percentile \\
Severe obesity & & $>99^{\text {th }}$ BMl percentile \\
\hline
\end{tabular}

Measurement of subcutaneous fat

Body fat percentage was determined by bioelectrical impedance (BIA). Bioelectrical impedance is based on body conductivity and depends on body hydration and its anatomy. It measures body composition by determining body resistance to electrical current of low intensity and high frequency. Measurements were performed on the InBody 220 device which uses the method of directly controlled bioimpedance analysis by the means of eight touch electrodes (http://www.inbody.cz/soubory/katalogy-pdf/inbody220_katalog-cz.pdf).

Body circumferences measurement

Body circumferences were measured with a measuring tape with the accuracy of $1 \mathrm{~cm}$. During measuring process the tape was close fitting to the skin without causing any compression. Children stood in a wide stance, neither abdominal nor any other muscle clenched.

Bustline was measured just below the shoulder blades at the back, and at the front, over the nipples for boys, and over the middle of the sternum for girls. Children were made to speak, and the data were taken at the moment of speaking in order to avoid breath withhold (Kleinwächterová \& Brázdová, 2001). Waistline was measured at the narrowest place from the front view, about $1-2 \mathrm{~cm}$ above the navel. Belly was not 
retracted. Hipline was measured at the widest part of the hips, at the level of the large trochanters, in the area of the greatest buttock convexity.

Group of children tested

This study processes the results of measurements in 25 children (10 boys and 15 girls) who participated in a curative stay at The Children's Treatment Centre of Křetín during 18th June - 16th July 2014. The age range of boys was $9-17$, age range of girls $8-17$ years.

\section{RESULTS}

After the admission to the Centre all children were measured for body weight and height, BMI calculation, the amount of subcutaneous fat and circumferences of chest, waist and hips. The same parameters were measured at the end of the stay after 4 weeks of the weight reduction programme. Body height, initial and final body weight and the initial and final BMI are given in Table II for boys and in Table III for girls.

Table 2. Body height, body weight initial and final, BMI initial and final in tested children - boys

\begin{tabular}{|c|c|c|c|c|c|c|c|c|}
\hline \multirow{2}{*}{ No. } & \multirow{2}{*}{$\begin{array}{c}\text { Age } \\
\text { [years] }\end{array}$} & \multirow{2}{*}{$\begin{array}{l}\text { Body } \\
\text { height } \\
{[\mathrm{cm}]}\end{array}$} & \multicolumn{3}{|c|}{ Body weight [kg] } & \multicolumn{3}{|c|}{ BMI } \\
\hline & & & initial & final & difference & initial & final & difference \\
\hline 1 & 13 & 165 & 71,9 & 71,6 & 3,3 & 27,5 & 26,3 & 1,2 \\
\hline 2 & 11 & 166 & 54,7 & 50,9 & 3,8 & 22,8 & 21,2 & 1,6 \\
\hline 3 & 12 & 151 & 68,5 & 63,6 & 4,9 & 30,1 & 27,9 & 2,2 \\
\hline 4 & 12 & 156 & 68,2 & 64,1 & 4,1 & 28,0 & 26,3 & 1,7 \\
\hline 5 & 9 & 140 & 52,0 & 48,0 & 4,0 & 26,6 & 24,5 & 2,1 \\
\hline 6 & 14 & 162 & 72,4 & 68,2 & 4,2 & 27,6 & 26,0 & 1,6 \\
\hline 7 & 17 & 174 & 95,8 & 89,1 & 6,7 & 31,6 & 26,4 & 2,2 \\
\hline 8 & 12 & 161 & 76,3 & 69,8 & 6,5 & 29,4 & 26,9 & 2,5 \\
\hline 9 & 12 & 172 & 96,8 & 90,9 & 5,9 & 32,7 & 30,7 & 2,0 \\
\hline 10 & 13 & 157 & 65,1 & 59,4 & 5,7 & 26,4 & 24,1 & 2,3 \\
\hline
\end{tabular}

Table 3. Body height, body weight initial and final, BMl initial and final in tested children - girls

\begin{tabular}{ccccccccc}
\hline & \multirow{2}{*}{$\begin{array}{c}\text { Age } \\
\text { No. }\end{array}$} & $\begin{array}{c}\text { Body } \\
\text { [years] }\end{array}$ & \multicolumn{3}{c}{ height } \\
\cline { 5 - 9 } & {$[\mathrm{cm}]$} & initial & final & difference & initial & final & difference \\
\hline 1 & 11 & 152,0 & 73,4 & 68,3 & 5,1 & 31,8 & 29,6 & 2,2 \\
2 & 17 & 163,5 & 73,0 & 70,1 & 2,9 & 27,3 & 26,2 & 1,1 \\
3 & 9 & 147,0 & 48,8 & 46,0 & 2,8 & 22,6 & 21,3 & 1,3 \\
4 & 13 & 167,0 & 86,4 & 81,8 & 4,6 & 31,0 & 29,3 & 1,7 \\
5 & 15 & 162,0 & 88,5 & 85,3 & 3,2 & 33,7 & 32,5 & 1,2 \\
6 & 15 & 167,0 & 84,7 & 81,3 & 3,4 & 30,4 & 29,1 & 1,3 \\
7 & 13 & 143,0 & 91,6 & 86,0 & 5,6 & 28,3 & 26,6 & 1,7 \\
8 & 9 & 143,0 & 50,6 & 48,0 & 2,6 & 24,7 & 23,5 & 1,2 \\
9 & 8 & 137,0 & 48,1 & 45,1 & 3,0 & 25,6 & 24,1 & 1,5 \\
10 & 15 & 167,0 & 75,4 & 73,3 & 2,1 & 27,1 & 26,3 & 0,8 \\
\hline
\end{tabular}




\begin{tabular}{lllllllll}
11 & 14 & 155,0 & 68,9 & 64,0 & 4,9 & 27,8 & 25,8 & 2,0 \\
12 & 12 & 157,0 & 61,9 & 59,3 & 2,6 & 25,1 & 24,1 & 1,0 \\
13 & 14 & 162,5 & 83,8 & 81,1 & 2,7 & 31,7 & 30,7 & 1,0 \\
14 & 13 & 164,0 & 83,6 & 79,0 & 4,6 & 31,1 & 29,4 & 1,7 \\
15 & 12 & 150,0 & 63,2 & 59,9 & 3,3 & 28,1 & 26,6 & 1,5 \\
\hline
\end{tabular}

The amount of body fat before admission and after completion of the program at the Centre is given in Table IV for boys and Table $V$ for girls.

Table 4. The amount of body fat initial and final in tested children- boys

\begin{tabular}{ccccc}
\hline \multirow{2}{*}{ No. } & Age & \multicolumn{3}{c}{ Fat amount [\%] } \\
\cline { 3 - 5 } & [years] & initial & final & difference \\
\hline 1 & 13 & 27,5 & 24,2 & 3,3 \\
2 & 11 & 17,4 & 14,2 & 3,2 \\
3 & 12 & 31,7 & 28,8 & 2,9 \\
4 & 12 & 27,1 & 23,2 & 3,9 \\
5 & 9 & 20,8 & 18,3 & 2,5 \\
6 & 14 & 23,8 & 21,1 & 2,7 \\
7 & 17 & 28,8 & 24,4 & 4,4 \\
8 & 12 & 28,4 & 22,7 & 5,7 \\
9 & 12 & 42,3 & 36,2 & 6,1 \\
10 & 13 & 20,0 & 14,1 & 5,9 \\
\hline
\end{tabular}

Table 5. The amount of body fat initial and final in tested children - girls

\begin{tabular}{ccccc}
\hline \multirow{2}{*}{ No. } & Age & \multicolumn{3}{c}{ Fat amount [\%] } \\
\cline { 3 - 5 } & [years] & initial & final & difference \\
\hline 1 & 11 & 32,2 & 28,7 & 3,5 \\
2 & 17 & 25,1 & 23,4 & 1,7 \\
3 & 9 & 15,0 & 11,5 & 3,5 \\
4 & 13 & 35,6 & 31,9 & 3,7 \\
5 & 15 & 37,3 & 34,1 & 3,2 \\
6 & 15 & 41,1 & 37,7 & 3,4 \\
7 & 13 & 33,5 & 29,6 & 3,9 \\
8 & 9 & 19,9 & 17,6 & 2,3 \\
9 & 8 & 21,8 & 19,1 & 2,7 \\
10 & 15 & 27,0 & 26,4 & 0,6 \\
11 & 14 & 21,8 & 19,8 & 2,0 \\
12 & 12 & 19,1 & 18,8 & 0,3 \\
13 & 14 & 40,5 & 38,2 & 2,3 \\
14 & 13 & 34,6 & 33,0 & 1,6 \\
15 & 12 & 24,8 & 21,3 & 3,5 \\
\hline
\end{tabular}


Circumference of chest, waist and hips measured at the moment of admission to the Centre and after 4week weight reduction programme are given in Table VI for boys and Table VII for girls.

Table 6. Circumference of chest, waist and hips initial and final in tested children - boys

\begin{tabular}{|c|c|c|c|c|c|c|c|c|c|c|}
\hline \multirow{3}{*}{ No. } & \multirow{3}{*}{ Age } & \multicolumn{9}{|c|}{ Body circumferences $[\mathrm{cm}]$} \\
\hline & & \multicolumn{3}{|c|}{ Chest } & \multicolumn{3}{|c|}{ Waist } & \multicolumn{3}{|c|}{ Hips } \\
\hline & & initial & final & difference & initial & final & difference & initial & final & difference \\
\hline 1 & 13 & 94 & 90 & 4 & 93 & 86 & 7 & 95 & 95 & 0 \\
\hline 2 & 11 & 78 & 79 & -1 & 83 & 76 & 7 & 86 & 85 & 1 \\
\hline 3 & 12 & 86 & 84 & 2 & 87 & 86 & 1 & 103 & 100 & 3 \\
\hline 4 & 12 & 84 & 81 & 3 & 91 & 81 & 10 & 103 & 100 & 3 \\
\hline 5 & 9 & 84 & 82 & 2 & 82 & 80 & 2 & 100 & 99 & 1 \\
\hline 6 & 14 & 96 & 96 & 0 & 88 & 83 & 5 & 100 & 99 & 1 \\
\hline 7 & 17 & 104 & 102 & 2 & 99 & 90 & 9 & 108 & 104 & 4 \\
\hline 8 & 12 & 84 & 82 & 2 & 82 & 80 & 2 & 94 & 91 & 3 \\
\hline 9 & 12 & 109 & 100 & 9 & 103 & 97 & 6 & 112 & 110 & 2 \\
\hline 10 & 13 & 85 & 83 & 2 & 85 & 76 & 9 & 101 & 97 & 4 \\
\hline
\end{tabular}

Table 7. Circumference of chest, waist and hips initial and final in tested children - girls

\begin{tabular}{|c|c|c|c|c|c|c|c|c|c|c|}
\hline \multirow{3}{*}{ No. } & \multirow{3}{*}{ Age } & \multicolumn{9}{|c|}{ Body circumferences [cm] } \\
\hline & & \multicolumn{3}{|c|}{ Chest } & \multicolumn{3}{|c|}{ Waist } & \multicolumn{3}{|c|}{ Hips } \\
\hline & & initial & final & difference & initial & final & difference & initial & final & difference \\
\hline 1 & 11 & 87 & 83 & 4 & 83 & 81 & 2 & 102 & 100 & 2 \\
\hline 2 & 17 & 79 & 76 & 3 & 74 & 72 & 2 & 100 & 100 & 0 \\
\hline 3 & 9 & 74 & 71 & 3 & 67 & 64 & 3 & 86 & 80 & 6 \\
\hline 4 & 13 & 89 & 87 & 2 & 88 & 84 & 4 & 111 & 107 & 4 \\
\hline 5 & 15 & 96 & 92 & 4 & 93 & 93 & 0 & 109 & 107 & 2 \\
\hline 6 & 15 & 90 & 86 & 4 & 90 & 87 & 3 & 107 & 103 & 4 \\
\hline 7 & 13 & 89 & 87 & 2 & 86 & 84 & 2 & 106 & 106 & 0 \\
\hline 8 & 9 & 72 & 71 & 1 & 74 & 70 & 4 & 90 & 88 & 2 \\
\hline 9 & 8 & 76 & 75 & 1 & 77 & 73 & 4 & 86 & 86 & 0 \\
\hline 10 & 15 & 85 & 83 & 2 & 79 & 78 & 1 & 103 & 103 & 0 \\
\hline 11 & 14 & 81 & 78 & 3 & 76 & 73 & 3 & 98 & 95 & 3 \\
\hline 12 & 12 & 79 & 77 & 2 & 74 & 72 & 2 & 94 & 91 & 3 \\
\hline 13 & 14 & 85 & 84 & 1 & 85 & 82 & 3 & 113 & 110 & 3 \\
\hline 14 & 13 & 91 & 87 & 4 & 91 & 87 & 4 & 110 & 104 & 6 \\
\hline 15 & 12 & 77 & 77 & 0 & 79 & 76 & 3 & 94 & 93 & 1 \\
\hline
\end{tabular}




\section{DISCUSSION}

After completion of the curative stay all children showed some weight reduction. The most significant weight loss was reported in a 17 year old boy (no. 7) who lost $6.7 \mathrm{~kg}$ per 4-week stay. It is however essential to mention the fact that the boy had weighed $95.8 \mathrm{~kg}$ at the moment he was admitted to the Centre and $89.1 \mathrm{~kg}$ when he was released, which means that he had been defined as obese at admission and "just" overweight at release. The least weight loss, merely $2.1 \mathrm{~kg}$, was reported in a 15 year old girl (no. 10). She did, however, show an improvement in her BMI, which was above the 97th percentile at admittance, and just above 97th percentile at release. BMI in all children decreased after participating in the programme. None of the children grew in height; weight loss was the only reported change. The difference in boys was $1.94 \pm 0.40$, in girls $1.41 \pm 0.39$ on average. The greatest BMI decrease (of 2.5) was reported in a boy aged 12 (no. 8), and the smallest (0.8) in a girl aged 15 (no 10). In both of these children the BMI remained above the 97 th percentile after the curative stay, i.e. within the zone of morbid obesity. Similarly the amount of body fat was lower in all children at the end of the curative stay. The decrease of body fat in boys was $4.06 \pm 1.39 \%$, and in girls of $2.55 \pm 1.13 \%$ on average. The greatest decrease of body fat was reported in another 12 year old boy (no. 9), and the smallest decrease in a 12 year old girl (no. 12). The boy's BMI at admission and at release was above the 97 th percentile, the girl belonged to 75th percentile at admission and her BMI decreased to 60th percentile at release. The girl was not too obese, therefore even a very small decrease of body fat resulted in significant lowering of BMI.

The most significant reduction in bustline was seen in a boy aged 12 (no 9), in fact the same boy who showed the greatest fat loss. One boy, aged 11 (no.2) even showed an increase in the bustline of $1 \mathrm{~cm}$, which did not however represent a weight increase, since the boy lowered both BMI and amount of body fat. Thus the bustline enlargement was caused by the positive effect of sport activity. In the boy aged 14 (no. 6) no change in bustline was reported. As far as changes in waist circumference are concerned, the greatest decrease was achieved by a 12-years old boy (no. 4), whose waistline reduced by $10 \mathrm{~cm}$. In one 15-years old girl (no. 5), there was no change in a waistline reported. The greatest decrease in hip circumference was achieved by a 9-year old girl (no. 2) and a 13-years old girl (no. 14). Both girls reached a hip reduction of $6 \mathrm{~cm}$. Other children's results were as follows: a boy aged 13 (no. 1) and a girl aged 8 (no. 9), a girl aged 13 (no. 7) a girl aged 15 (no. 10) and a girl aged 17 (no. 2) reported no change in hipline. The decrease in circumference of bustline and waistline was on average much greater in boys than in girls - chest circumference of $2.5 \pm 2.7 \mathrm{~cm}$ (standard deviation greater than the average itself proves the inhomogeneity of the sample - children were different ages and age is an indicator of utmost importance for body circumferences measurement) and waist circumference of $5.8 \pm 3.2 \mathrm{~cm}$. Hipline decrease was much more significant in girls $-2.4 \pm 2.0 \mathrm{~cm}$ in average. This is predetermined by the different anatomy of adolescent boys and girls who represent a not negligible part of the tested group.

\section{CONCLUSIONS}

After 4-weeks of curative stay we can claim that the stay was $100 \%$ successful - all children lowered their body weight (and consequently also decreased their BMI). Boys lost $4.91 \mathrm{~kg}$, girls $3.56 \mathrm{~kg}$, on average. The average decrease in body fat was $4.06 \%$ in boys and $2.55 \%$ in girls. In regard to chest, waist and hips circumferences, the waistline showed the greatest reduction and was reduced by $5.8 \mathrm{~cm}$ in boys and by 2.7 $\mathrm{cm}$ in girls, on average. The question remains whether the children are capable of maintaining their reduced weight and fitter body after their return to their domestic environment. 


\section{REFERENCES}

1. Aldhoon Hainerová, I. (2009). Dětská obezita. Praha: Maxdorf.

2. Hainer, V. (2001). Obezita - minimum pro praxi. Praha: Triton.

3. Hainer, V. \& al. (2004). Základy klinické obezitologie. Praha: Grada Publishing, a. s.

4. Hlúbik, P. (2005). Epidemiologie a etiopatogeneze obezity. [online]. http://zdravi.el5.clanek/postgradualni-medicina/epidemiologie-a-etiopatogeneze-obezity-165979 download 5/11/2014.

5. Jihomoravské dětské léčebny, príspěvková organizace. www.detskelecebny.cz - download 15/11/2014.

6. Lékárna-Invest, S.R.O. (2007). http://www.inbody.cz/ soubory/katalogy-pdf/inbody220_katalogcz.pdf - download 20/11 2014.

7. Kleinwächterová, H. \& Brázdová, Z. (2001). Výživový stav člověka a způsoby jeho zjištování. Brno: Institute for next education of health care staffers.

8. Kunešová, M. (2004). Obezita - etiopatogeneze, diagnostika a léčba. Interní medicína pro praxi 20049 [online]. http://www.solen.cz/pdfs/int/2004/09/04.pdf - download 19/10 2014.

9. Pastucha, D., Ripplová, D., Vávrová, P., Hyjánek, J. \& Chrastina, J. (2010). Management multioborové spolupráce při léčbě dětské obezity. Profese on-line, 2010, III, 3, 175 - 184.

10. Prudilová, J. oral information, 2014.

11. Rikanová, I. (2012). Obezita u dětí. [bachelor's thesis]. Brno (CZ): Faculty of Sports Studies, Masaryk university.

12. Sigmund, E. \& Sigmundová, D. (2011). Pohybová aktivita pro podporu zdraví dětí a mládeže. Olomouc: Palacky university.

13. Svačina, Š. (2000). Obezita a diabetes. Praha: Maxdorf.

14. WHO (2007a). http://www.who.int/growthref/cht_bmifa_boys_perc_5_19years.pdf?ua=1 download 26/11 2014.

15. WHO (2007b). http://www.who.int/growthref/cht_bmifa_girls_perc_5_19years.pdf?ua=1 - download $26 / 112014$. 